\title{
Employee Engagement in the Public Sector: A Narrative Evidence Synthesis
}

\begin{abstract}
It has been claimed that employee engagement can harness public service motivation in ways that lead to better improve functioning and positive organizational outcomes, and can help address the increasingly complex challenges associated with public service in an era of austerity. Despite this, there has not yet been a systematic review of the literature that would enable researchers to understand more about the antecedent factors and the outcomes of engagement in the public sector. To address this issue, we undertook a systematic narrative synthesis of the empirical research on engagement that yielded 5771 published studies, of which just 59 were conducted in public sector settings and met our inclusion criteria. Studies generally found that motivational features of jobs (such as autonomy), groups (such as social support), management (such as leader consideration), and organizations (such as voice mechanisms) as well as psychological resources were key antecedents of engagement within the public sector; and that engagement was associated with positive employee health/morale and enhanced performance behaviors. The evidence was far from conclusive, suggesting a need for much more rigorous research focused on the specific challenges of public sector settings. We make recommendations for further research on this important topic, particularly with regards to understanding the connection between public service motivation and engagement and the need to examine engagement across different public sector/service contexts.
\end{abstract}

\section{Keywords:}

Public sector, public service motivation, employee engagement; evidence synthesis 


\section{INTRODUCTION}

The question of how public managers can motivate employees to deliver high quality public services in the face of organizational, societal, and political change is a core question of public management research (Kuipers et al., 2014; Vandenabelle, Brewer, \& Ritz, 2014). The concept of employee engagement represents a positive psychological experience that may provide insight into the motivational mechanisms that underpin the functioning and maintenance of public service motivation, and its link with performance and morale within the public sector (Bakker, 2015). Although there has been some discussion about the precise meaning of the term engagement (Schaufeli, 2014), it has been most commonly defined as a "positive, fulfilling, work-related state of mind" (Schaufeli et al., 2002: 74) comprising three facets: vigor, dedication and absorption. Thus, it is argued that individuals who are engaged in their work experience more positive emotions, concentrate harder and invest more energy into their jobs, than those who are not engaged (Schaufeli, 2014).

Public administration practitioners have welcomed engagement as a motivational tool to improve employee and public service outcomes. In the US, many Federal Agencies have utilized employee engagement surveys to understand how best to support and motivate employees to facilitate organizational transformation (Banks, 2006); and the US Department of Health and Human Services (2015) has emphasized the importance of raising levels of engagement in order to improve patient outcomes. Similarly in other countries, employee engagement has been measured and monitored by public sector organizations to help improve staff morale and performance. For example, in the UK, the Civil Service (Cabinet Office, 2015) and National Health Service (NHS) Trusts (NHS, 2015) have been required to participate in annual engagement 
surveys, and organizations such as NHS Employers (2015) provide extensive advice to public sector employers in how to raise levels of engagement amongst their workforce.

Despite the increasing interest in facilitating engagement within the public sector, there has hitherto been no synthesis of the evidence relating to engagement in the context of public service, and so it is unclear whether engagement is a useful and effective way to motivate and energize public sector workers. In particular, engagement has been heralded as a way in which employees can harness their own motivation and psychological resources to maintain high levels of performance and well-being within a demanding and changing work environment (Bakker, 2015; Schaufeli, 2014). Given that recent studies report widespread change in the way in which public sector staff work and are managed (Brown, 2004; Osborne, Radnor, Vidal, \& Kinder, 2014), coupled with reports of rising levels of work intensification and stress among public sector workers (Green, 2004; Korunga, Scharitzer, Carayons, \& Sainfort, 2003; Zeytinoglu et al., 2007), it is timely to examine the empirical evidence relating to engagement in public service. Moreover, there have been questions raised regarding the robustness, contextual sensitivity, and scope of the evidence base for engagement (Briner, 2014; Guest, 2014; Purcell, 2014), which further highlights the need to systematically review the empirical literature on engagement. Therefore, the purpose of this paper is to present, and summarize, the findings of a narrative evidence synthesis relating to engagement within the public sector as well as its antecedents and its outcomes in terms of individual morale and performance. We also aim to critically evaluate this evidence base and identify gaps that present as opportunities for future research.

\section{METHODS}

The review was undertaken as part of a wider systematic review of the engagement literature that included all sectors (Anonymous 2015). The approach for conducting narrative 
evidence syntheses as recommended by Briner (2011) was followed, adhering to the principles of organization, transparency and replicability. These ensured that the findings would be as robust and reliable as possible. The review followed the five stages described by Briner (2011) of planning; locating studies via a structured search; evaluating identified material against eligibility criteria; analysis and thematic coding; and finally reporting. Business Source Complete, International Bibliography for the Social Sciences, Nexis, Zetoc and Scopus were systematically searched for relevant, peer-reviewed articles published in the English language from 1990, the date when the first major peer-reviewed study focusing on engagement was published (Kahn, 1990), until October 2013 when the search took place. Initial search terms were developed by the research team and refined in discussion with academic and practitioner experts and through extensive piloting and re-testing. Only items that focused on antecedents and/or outcomes of engagement gathered from employees were initially selected. The research team imposed a quality threshold on those items to be taken forward for data extraction depending on the type of data gathered, and all items also had to demonstrate a clear logic between research questions, methods, sample, analysis and interpretation.

\section{Data Extraction}

5771 items published in peer-reviewed journals were identified as potentially relevant in the overall study and sifting took place in two stages. First, each abstract was reviewed by two researchers using a pro forma. In the case of disagreement, a third reviewer was involved. To ensure consistency of approach it was only after the research team reached a consensus (kappa) rating of 0.75 - interpreted as "substantial agreement" (Viera \& Garret, 2005: 361) that the review commenced. The review process led to the exclusion of a large number of items that failed to meet the quality and relevance thresholds, for example, some did not contain empirical data or did not 
focus on engagement. As a result of this, 172 empirical items were included in the full data extraction process for the study. Data from each item were summarized by a member of the research team using a specially designed form. The extracted data were checked again and synthesized in relation to the topics of 'antecedents', 'morale outcomes' and 'performance outcomes' by members of the research team responsible for each theme.

In order to select those that were particularly relevant to the public sector, we examined the reported methodology, sample characteristics, and data tables of the extracted items in more depth. We included any study where at least $75 \%$ of the sample comprised public sector workers or, if the sample was mixed, that public sector workers represented a reasonable number/proportion (judged in relation to research design/method) and were analyzed separately or comparatively with other subsamples. In order to help identify and confirm those studies that could be included as focusing on the public sector, we contacted the authors of 40 studies to clarify sample characteristics and other data queries. This was particularly the case for studies of dentists, teachers, and healthcare professionals where there may be a mix of public and private sector workers in these occupations in some countries. Where there was still ambiguity over the sample characteristics, for example if the author did not know the exact proportion of public sector workers, or the data/results for public sector workers, for example if correlational data for public sector subsamples could not be obtained, then the study was not included based on the need for rigor and validity.

Of the 172 extracted items that contained empirical data, 59 were found to report on studies that had taken place specifically in the public sector; the remaining 113 were excluded as they either focused on another sector, such as private or non-profit, or they mixed data from public and other sectors whereby data specific to the public sector could not be obtained. 


\section{RESULTS}

\section{Descriptives}

Table 1 examines the methodological and theoretical characteristics of the 59 included studies in terms of research design, sample characteristics, geographical location, definitions/measures, and theoretical foundations. This shows that the majority of studies were cross-sectional and self-report (41 studies); focused on healthcare or public education settings (40 studies); and took place in Continental Europe (i.e. Netherlands, Germany, Belgium, France, Switzerland), North America (i.e. USA, Canada) or Nordic Countries (i.e. Norway, Finland, Denmark) (37 studies). Very few studies collected data from multiple sources, different public sector occupations, or from more than one country.

The vast majority (52 studies) utilized Schaufeli et al.'s (2002) work engagement perspective, which views engagement as a positive work-related psychological state that connotes an energetic involvement with one's work activities. It is typically measured with 17 or 9 item versions of the Utrecht Work Engagement Scale (UWES; Schaufeli \& Bakker, 2003), which assesses the frequency with which an individual feels vigoros (e.g., bursting with energy), dedicated (e.g., feeling proud of the work they do), and absorbed (e.g., feeling immersed in their work). The theoretical foundations of Schaufeli et al.'s (2002) work engagement construct are grounded in the job demands-resources model (Bakker \& Demerouti, 2008), which itself is related to the psychological theories of conservation of resources (Hobfoll, 1989) and broaden-and-build (Fredrickson, 2001). Thus, it is unsurprising that these were the main theoretical frameworks adopted by studies to explain their hypotheses and findings (36 studies). This collection of theories broadly argue that individuals seek personal development and growth through particular emotional, psychological, and job-related resources. These resources trigger motivational 
processes that promote engagement, which in turn, facilitates healthy, productive working. However, there were a range of other definitions, measures, and theories that were applied in some of the studies. These drew mainly from Kahn's (1990) personal role engagement perspective that views engagement as a socially embedded and role-based phenomenon or Saks's (2006) perspective that views engagement as a multi-foci concept that is underpinned by the social exchange relationship between the employee and the employer.

Insert Table 1 about here

Table 2 summarizes the findings from the included studies, and those in shaded rows in the table were regarded by the research team as being of especially high quality in terms of the complexity and reliability of methods used, in other words, they involved either data collected at several time points or multiple raters, or both.

\section{Antecedents}

Fifty-one studies examined various antecedents and their association with engagement which fell into five categories (totalling more than 51 as some included more than one antecedent), including: job design (25 studies); perceptions of organization/team (22 studies); psychological states (16 studies); leadership and management (10 studies) and experience of specific interventions/ organizational activities (four studies). Many studies considered antecedent factors with different outcomes and are thus also reported on in subsequent sections.

Job design. Ten studies found a positive association between various types of job resources (measured as a collective factor) and engagement, including for example organizational support, job control, pride in work. However, only one of these used multiple time points (Ouweneel, Le Blanc, \& Schaufeli, 2012), and this found that job resources at time 1 were not significantly related 
to engagement at time 2 (six months later). A number of others examined the effect of individual job design characteristics whereby job autonomy/control (e.g., Biggs, Brough, \& Barbour, 2013; Mauno, Kinnunen, \& Ruokolainen, 2007), opportunities for development/learning (e.g., Bakker \& Bal, 2010; Opie et al., 2011), skill discretion (Adrianssens. De Gucht, van der Doef, \& Maes 2011), and job complexity (Hornung et al., 2010) were all positively related to engagement. The most persuasive of these are the studies by Mauno et al. (2007), Weigl et al. (2010), and Biggs et al. (2013). The latter two surveyed participants at three time points spanning a total of 2.5 years with both finding reciprocal/gain spiral effects of job autonomy/control and engagement. However, Mauno et al.'s (2007) two-wave ( 2 year interval) longitudinal survey of 409 employees in a health care organization in Finland, revealed that although job control was associated most strongly with the dimensions of engagement, these relationships mostly became non-significant after controlling for baseline levels of work engagement. A small number focused on characteristics that were particularly salient within the healthcare context. Bamford, Wong and Spence Laschinger (2013) and Spence Laschinger (2010) both sampled nurses in Canada and found a positive association between person-job match (particularly of control, reward, fairness, and values) and engagement.

Twelve studies looked at job demands, such as workload, emotional demands, and time pressures, of which two were longitudinal (Kühnel \& Sonnentag, 2011; Mauno et al., 2007). The evidence from these studies was equivocal; some found a negative link between demands and engagement (e.g., Hakanen, Bakker and Demerouti 2005; Hu, Schaufeli, \& Taris 2011), but others found no or weak associations (e.g., Gorter \& Freeman 2011; Taipale et al., 2011). The most persuasive evidence comes from the two longitudinal studies, which both found that the relationships between demands and engagement mostly became non-significant when examining effects over time (Kühnel \& Sonnentag, 2011; Mauno et al., 2007). Lastly, a few studies also 
explored potential interaction effects of demands and resources on engagement, with most finding that the negative relationship between demands and engagement was strongest when resources were scarce (e.g., Hakenen et al., 2005; Hu et al., 2011). However, Taipale et al. (2011) found this interaction to be weak, and van den Broeck et al. (2011) found that workload boosted the positive association between job autonomy and engagement whereas weakened the positive relationship between learning opportunities and engagement.

Perceptions of organizational and team factors. Twenty two studies met the inclusion criteria, of which the strongest evidence was presented by two longitudinal studies and one mixed methods study. Over three waves, spanning a total of 2.5 years, Weigl et al. (2010) found a link between work relationships and engagement within a healthcare setting, based on the quality of cooperation and inter-personal relationships among and between co-workers and supervisors, where quality was assessed in terms of trust and a lack of conflict or teamwork. A three wave (spanning a total of 30 months) study within the Australian police service by Biggs et al. (2013) demonstrated that there were reciprocal relationships between strategic alignment, social support, and engagement. By utilizing a mixed methods approach, Abdelhadi and Drach-Zahavy (2012) found a positive association between service climate and engagement within a healthcare setting, where service climate was measured as a ward-level construct reflecting socially shared perceptions about service quality (empathy, courtesy and organizational citizenship behaviors) in relation to patient-centred care.

Other studies investigating perceptions of organizational or team factors and their association with engagement adopted a cross-sectional methodology. Two studies examined perceptions of the psychological contracts and found the relational contracts were beneficial for engagement (Bal \& Kooij; 2011; Bal et al., 2013). Others focused on aspects of support and found 
positive effects of support from co-workers/organization (e.g., Rich, LePine, \& Crawford, 2010; Freeney \& Fellenz 2013) as well as of structural empowerment (e.g., Spence Laschinger, Wilk, Cho, and Greco, 2009). However, Adriaessens et al. (2011) found that colleague support was not a significant predictor of nurses' engagement when considered alongside other job and organizational factors. Others focused on work group effects, and found that group trust/conflict (Selmer Jonasson, \& Lauring, 2013), bullying/harassment (Cogin \& Fish, 2009), and team-level engagement (Bakker, van Emmerik, \& Euwema, 2006) influenced engagement, whilst others focused on organizational level practices/processes, with these finding that employee perceptions of HR practices, such as rewards (Adrienssens et al., 2011), family support (Anaza \& Rutherford, 2012a), and development (Bal et al., 2013), were related to engagement.

Individual psychological states. Sixteen studies investigated the relevance of individual psychological states within wider models of engagement in the public sector context; four of these were of particular note since they used complex methods. Kühnel and Sonnentag's (2011) four wave study of teachers, spanning one day before to four weeks following a vacation, found that relaxation experiences related to fade in engagement, yet these experiences did not explain significant additional variance after four weeks post-vacation. Weigl et al. (2010) demonstrated in a three wave study spanning a 2.5 year period that hospital physicians who utilized active coping techniques were more engaged than those who did not. Ouweneel et al. (2012) found, in a sample of University workers, that personal resources, consisting of hope, optimism, and self-efficacy, were positively associated with engagement six months later. In a related study using a similar sample, Ouweneel, Le Blanc, Schaufeli, and van Wijhe (2012) showed that positive emotions and engagement were positively related at the day-level, and that hope, a specific personal resource, mediated this relationship. Further cross-sectional, self-report studies found similar relationships 
between positive psychological states and engagement; for example, Van Beek et al. (2012) and Gillet et al. (2013) found that motivation was linked with engagement; Spence Laschinger, Grau, Finegan, and Wilk (2012), and del Libano, Llorens, Salanova, and Schaufeli (2012) found that personal resources, such as self-efficacy, were linked with engagement; and Rich et al. (2010) and van den Broeck et al. (2011) showed that engagement is higher when individually held values are congruent with those of the organization and are intrinsically orientated compared to when they are neither congruent nor intrinsically orientated. Two of these cross-sectional studies provided evidence that personal resources, such as self-efficacy, and positive affect are potential mediators of the relationship between job resources and engagement (Bakker \& Xanthopoulou, 2013; Balducci, Schaufeli, \& Fraccaroli, 2011).

Perceived leadership and management. Ten studies examined the links between engagement and aspects of leadership - including ethical, authentic, and transformational leadership styles (Bamford et al., 2013; Tanner et al., 2010; Wong, Laschinger, \& Cummings, 2010) - and aspects of management - such as supervisory support/coaching (e.g., Gillet et al., 2013; Othman \& Nasurdin 2012). Two of these used complex methods: Hornung et al. (2011) in a twowave study, spanning one year, found that leader consideration was linked with engagement for medical doctors; and Vogelgesang, Leroy, and Avolio (2013) in a three-wave study, spanning nine weeks, found that for military cadets group-level leader communication transparency positively predicted individual follower engagement, and this relationship was mediated by leader behavior integrity.

Organizational interventions or activities. Although of interest to practitioners, only four research studies reported on individual responses to organizational interventions or activities. Rickard et al. (2012) found that engagement levels did not significantly change amongst a large 
group of hospital nurses and midwives following a workload intervention exercise that included a nursing workload tool, personal development and increased staffing levels. Ratnasingham et al. (2012) found that employees using on-site childcare were less engaged when they perceived their employer to be unsupportive. Both Arrowsmith and Parker (2013) and Reisnner and Pagan (2013) conducted qualitative studies within specific organizational settings undergoing change, and revealed that the approach and methods, such as communication and voice, used by HR managers and line managers to engage employees is particularly important to how engagement is experience during such circumstances. Given the small number of studies, it is difficult to draw substantive conclusions from this area of focus.

\section{Morale Outcomes}

Sixteen studies met the inclusion criteria; morale outcomes were grouped under two headings: wellbeing and health perceptions, and work-related attitudes. Only one of the 16 studies was longitudinal (Hakanen \& Schaufeli, 2012), and this study found a positive association between engagement and life satisfaction and a negative association between engagement and exhaustion as well as depressive symptoms. Three studies found a link between engagement and general/psychological health (Freeney \& Fellenz, 2013; Poulsen et al., 2012; Simbula, 2010), and one study showed mixed support for the positive relationship between engagement and various dimensions of work ability (Arilia et al., 2012). Three studies found mixed support for a negative association between engagement and dimensions of burnout, particularly emotional exhaustion (Hoigaard, Giske, \& Sundsli, 2012; Simbula, 2010; Vera, Salanova, \& Martin, 2010). Eight crosssectional studies found that engagement was positively associated with job satisfaction (e.g., Klassen et al., 2012; Van Bogaert et al., 2013) with one also showing a positive link between engagement and career satisfaction (Spence-Laschinger, 2012). Three found a link with 
organizational commitment (Brunetto, Teo, Shacklock, \& Farr-Wharton, 2012; del Libano et al., 2012; Hu et al., 2011), and seven found a link between high levels of engagement and low levels of intent to quit one's job or career (e.g. Forbes, Freeman, McCombes, \& Humphris, 2013; Spence Laschinger, 2012).

\section{Engagement and Performance}

Ten studies examined the relationship between engagement and at least one performance outcome. Five studies explored the relationship between engagement and individual in-role performance. Two of these focused on the healthcare sector with one examining individual-level quality of care, and the other work effectiveness. Abdelhadi and Drach-Zahavy (2012) demonstrated that engagement was positively related to nurses' patient centred care, as measured by structured observations, and Spence Laschinger et al.'s (2009) study revealed a positive association between engagement and perceived work effectiveness. The remaining three examined in-role performance across other occupational groups (teachers, police officers, military cadets), with all three finding a positive association between engagement and in-role performance. Of particular note are Vogelgesang et al. (2013) who used objective performance data, and Rich et al. (2010) who captured supervisor-rated performance. Three examined the link between engagement and quality of care at the team or unit level. Van Bogaert et al. (2013) showed that, after controlling for other factors, unit-level dedication and absorption (but not vigor) were positively related to nurse-reported quality of care by the interdisciplinary team. They did not find evidence of a relationship between any of the three engagement facets and nurse-reported quality of care at the unit or and shift levels, respectively. In contrast, Wong et al.'s (2010) study showed that engagement was positively associated with nurses' perception of unit care quality. Similarly, Freeney and Fellenz (2013) demonstrated that engagement was positively related to quality of 
care, using a combined measure of unit and shift level care quality. Four studies explored the relationship between engagement and extra-role performance outcomes. Rich et al. (2010) and Sulea et al. (2012) found a positive relationship between engagement and organizational citizenship behavior in a sample of firefighters and in a mixed sample of public sector workers, respectively. Bakker and Xanthopoulou (2013) found a positive link between a female school principal's engagement and their creativity, rated by other teachers; and Wong et al.'s (2010) study revealed that engagement was positively related to nurses' voice behavior. One study found that engagement was linked with low counterproductive work behavior in a mixed sample of public sector workers (Sulea et al., 2012).

Most of the ten studies that explored the relationship between engagement and performance outcomes also examined whether engagement mediates the relationship between work contextual factors and performance. These found support for the mediating role of engagement in the relationships between job resources (Bakker \& Bal, 2010; Bakker \& Xanthopoulou, 2013), personal/psychological resources (Bakker \& Xanthopoulou, 2013; Rich et al., 2010; Sulea et al., 2012), social/organizational support (Freeney \& Fellenz, 2013; Rich et al., 2010; Sulea et al., 2012), and leadership (Wong et al., 2010) and performance outcomes. Most of these showed that engagement partially mediated these relationships

Insert Table 2 about here

\section{DISCUSSION}

We conducted a narrative evidence synthesis focusing on the antecedents and outcomes of engagement amongst public sector workers. Through a process of structured search and sifting, we identified 59 items that were relevant and met the quality threshold. Although many used cross- 
sectional, self-report data that limited the overall validity of the evidence, there were a few complex studies that used mixed methods, multi-level, time-lagged, or longitudinal designs, which we highlighted as providing more robust and persuasive forms of evidence.

Overall, the studies indicated that motivational features of the job (e.g., autonomy/control, opportunities for learning), workgroup (e.g., social support, service climate), management (e.g., leader consideration, supervisory support) and organization (e.g., family supportive practices, voice mechanisms) were positively related to engagement. Moreover, positive emotions and personal resources were strongly associated with engagement. Given the nature of public service motivation as an important psychological resource for public sector employees (Bakker, 2015; Vandenabeele et al., 2014), it will be useful to further examine which internal resources and motivations are particularly salient for engagement within the public sector context. An additional question is also whether engagement with the job 'crowds out' the original public service motivation concept which is focused on the notion of being a good public servant, i.e. to what extent does engagement offer a complementary, alternative, or encompassing perspective of motivation and behaviour of public sector workers? The relevance and differentiation of demands within various public services should also be further theorized and investigated as the evidence was mixed, with some suggesting that demands also have a moderating effect on the relationship between particular resources and engagement. A contributing factor for the inconsistency in findings may be that job demands can constitute either challenge demands, which can act as motivators, or hindrance demands, which can lead to lower levels of performance (Crawford, Lepine, \& Rich 2010).

With regard to outcomes, the evidence from the studies generally supported claims that engagement facilitates performance within the public sector, particularly with regard to individual- 
level in-role and extra-role performance behaviors. Some of these studies also showed how engagement was a mediating process through which perceptions of the work context within public sector institutions influenced employee behavior and performance. Despite this, the evidence was less clear about group and organizational level outcomes as well as about the specific public service benefits of having highly engaged staff. Future research should therefore focus on exploring the effects of engagement on public service provision, delivery, and outcomes; as well as on how engagement relates to change attitudes in the public sector. The evidence also suggested that high levels of engagement were associated with a range of work attitudes such as job satisfaction and low intentions to quit, and with positive well-being/health indicators, such as life satisfaction. However, the evidence that engagement is linked with lower levels of negative wellbeing/health was more mixed. Theories and models of engagement applied to the public sector, such as the one presented by Bakker (2015), should therefore include potential psychological and health benefits.

There are two important contextual issues that arose from the findings. Firstly, healthcare and public education occupations have received the most attention by engagement researchers. Most of these studies focused on occupational antecedents rather than on examining engagement's wider nomological net that is salient to providing a public health or educational service. Moreover, many studies examined the same antecedents and outcomes as those in the general workforce (cf. Anonymous, 2015), and so there are a lack of studies that focus on the particularities of the public sector context. Studies should therefore develop a holistic understanding of engagement and its antecedents/outcomes within the context of what is relevant and important within a particular public service. For example, some studies within the healthcare context suggest that the social/organizational environment is particularly important for the quality of patient care, and that 
engagement is a key psychological process that translates positive environmental conditions into these care-related outcomes (Abdelhadi \& Drach-Zahavy, 2012; Freeney \& Fellenz, 2013; SpenceLaschinger et al., 2009; van Bogaert et al., 2013). In contrast, specific job-related resources, such as autonomy and opportunities for development, are important for engagement and performance of those in educational contexts (Bakker \& Bal, 2010; Bakker \& Xanthopoulou, 2013). Therefore, future research, particularly using a mixed methods approach, should compare and contrast the experience of engagement within different public services to determine which antecedents and outcomes are more or less salient in different service contexts. This will develop more nuanced recommendations concerning the use of engagement as a management practice across different public service contexts, as well as a better understanding of the commonalities and particulars of the engagement experience within the public sector as whole.

Secondly, the majority of studies were conducted either in Continental Europe or in North America. This echoes Rothmann's (2014) observation that most engagement studies have been conducted in democratic, highly individualistic countries, which raises the question of whether the antecedents, experience, and outcomes of engagement are applicable to those countries that are culturally and politically very different from the US and Europe. The influence of national cultures and values, political structures and ideologies, and economic activities are all likely to influence the way in which public service work is designed, organized, and perceived (Brown \& Humphreys, 1995; Capell et al., 2013; Kim, 1999). Furthermore, ideas of public sector and public service vary across different international contexts not just in terms of extent (e.g., expansive models of public sector in Scandinavia; mixed-market models of public services in the UK and Europe; limited state sponsored enterprises in the US), but also in terms of ideological positions on the role of government in serving public interests. Therefore the dynamics and processes of engagement for 
public sector employees are likely to vary across countries. Very few of the included studies compared or collected data from different countries that represent a variety of public sector and welfare systems. However, the initial evidence from this review supports the need for future crosscultural research on engagement within the public sector. For instance, Klassen et al.'s (2012) study of school teachers in Australia, Canada, China, Indonesia, and Oman found that the factor structure of the UWES measure of engagement varied across countries; and Taipale et al.'s (2011) study in eight European countries found some variation in the levels of demands/resources as well as the strength of the relationship between these antecedents and engagement across countries.

\section{Practical Implications}

The findings of this review have a number of potential implications for practice within a public sector context. Overall, the review lends cautious support to the notion that raised levels of engagement are beneficial for public sector organizations and individual public employees. Given the relatively small number of studies included, and doubts as to whether these are premised on the most appropriate conceptualizations for public sector contexts, there is clearly a need for further research on all aspects of engagement in the public sector before any definitive views can be reached. Nevertheless, it would be in the interests of practitioners to consider ways of raising and maintaining staff engagement levels. There was some evidence that raising levels of staff autonomy/control (Biggs et al., 2013; Weigl et al., 2010), providing positive working environments (Abdelhadi \& Drach-Zahavy, 2012), and developing the individualized relationship with managers/leaders (Hornung et al., 2011; Vogelgesang et al., 2013) would be advantageous for improved engagement.

Of particular interest is the link between engagement and coping strategies in the public sector context, usually identified as personal resources in terms of experiencing hope, optimism 
and self-efficacy (Ouweneel et al., 2012) or actively coping in difficult settings (Weigl et al., 2010). Evidence also suggests a link between engagement and resilience which, from studies in the wider workforce, is defined as "the ability to adapt one's level of control temporarily up or down as circumstances dictate" (Bakker \& Xanthopolou, 2013: 2763). While there are very few studies which have explored the link between engagement and resilience specifically in public sector settings, the evidence suggests testing and developing different organizational interventions designed to build personal and team resilience may be a productive way to foster high levels of engagement which, given the current complexities and costs of public service planning and delivery, is of strategic importance to practice (Bargagliotti, 2012).

\section{Limitations}

Despite initial indications of a large body of evidence on engagement, the key limitation of this study is the small body of research that underpins understanding of engagement in the public sector context. Moreover, many of the included studies were cross-sectional and based on selfreport surveys, and therefore it is difficult to be sure of the direction of causality, or to determine whether common method bias is relevant. There was little evidence of public sector-specific studies (rather it was the occupation that was the focus of study), thus suggesting that a theoretically coherent body of evidence specific to the public sector is lacking. The majority of research has focused on perceptions of the work context and their link with engagement as a psychological state and so many studies have not examined issues of most interest and relevance to practitioners, such as the impact of initiatives aimed at raising engagement levels. Finally, the vast majority of the included studies adopted a purely quantitative, resource-based perspective grounded in Schaufeli et al.'s (2002) work engagement construct. This perspective is increasingly being criticized as too acontextual, transactional, and narrow in its view of work relations and the 
motivational processes that underpin human behavior at work (Bargagliotti, 2012; Purcell, 2014). Therefore, the evidence base of engagement within the public sector may represent a fairly restricted view of motivation and behavior of public service employees.

\section{Conclusion}

This review is the first narrative evidence synthesis that has been conducted with a focus on engagement amongst public sector workers. It therefore brings together all the peer-reviewed articles published since 1990 on engagement that meet stringent quality thresholds and provides a useful resource for public sector managers and practitioners. Overall, it can be concluded that some support has been found for the notion that engagement is associated with beneficial personal and performance outcomes within the public sector, but that further research, particularly longitudinal and multi-source, is needed to establish this with any certainty. Despite this, there are valuable opportunities to examine how the antecedents, experiences, and outcomes of engagement within the public sector vary across different occupational and cultural contexts. Moreover, establishing the nature of public service motivation as a unique psychological resource of public sector workers and its relationship with engagement alongside other resources will help to advance our understanding of the psychological features of public service work. 


\section{REFERENCES}

* denotes studies included in the evidence synthesis

*Abdelhadi, N., \& Drach-Zahavy, A. 2012. Promoting patient care: Work engagement as a mediator between ward service climate and patient-centred care. Journal of Advanced Nursing, 68: $1276-1287$.

*Adriaenssens, J., De Gucht, V., Van der Doef, M., \& Maes, S. 2011. Exploring the burden of emergency care: Predictors of stress - health outcomes in emergency nurses. Journal of Advanced Nursing, 67: 1317-1328.

*Airila, A., Hakanen, J., Punakallio, A., Lusa, S., \& Luukkonen, R. 2012. Is work engagement related to work ability beyond working conditions and lifestyle factors?. International Archives of Occupational and Environmental Health, 85: 915-925.

*Anaza, N. A., \& Rutherford, B. 2012. How organizational and employee-customer identification, and customer orientation affect job engagement. Journal of Service Management, 23: 616-639.

*Anaza, N. A., \& Rutherford, B. N. 2012. Developing our understanding of patronizing frontline employees. Managing Service Quality: An International Journal, 22: 340-358.

Anonymous 2015. Details omitted for double-blind reviewing

*Arrowsmith, J., \& Parker, J. 2013. The meaning of 'employee engagement' for the values and roles of the HRM function. The International Journal of Human Resource Management, 24: 2692-2712.

Bakker, A. B. 2015. A job demands-resources approach to public service motivation. Public Administration Review, 75: 723-732.

*Bakker, A. B., \& Bal, M. P. 2010. Weekly work engagement and performance: A study among starting teachers. Journal of Occupational and Organizational Psychology, 83: 189-206.

Bakker, A. B., \& Demerouti, E. 2008. Towards a model of work engagement. Career Development International, 13: 209-223.

*Bakker, A.B., \& Xanthopoulou, D., 2013. Creativity and charisma among female leaders: The role of resources and work engagement. International Journal of Human Resource Management, 24: 2760-2779.

*Bakker, A. B., van Emmerik, H., \& Euwema, M. C. 2006. Crossover of burnout and engagement in work teams. Work and Occupations, 33: 464-489.

*Bakker, A. B., Hakanen, J. J., Demerouti, E., \& Xanthopoulou, D. 2007. Job resources boost work engagement, particularly when job demands are high. Journal of Educational Psychology, 99: 274-284.

*Bal, P. M., \& Kooij, D. 2011. The relations between work centrality, psychological contracts, and job attitudes: The influence of age. European Journal of Work and Organizational Psychology, 20: 497-523. 
*Bal, P. M., De Cooman, R., \& Mol, S. T., 2013. Dynamics of psychological contracts with work engagement and turnover intention: The influence of organizational tenure. European Journal of Work and Organizational Psychology, 22: 107-122.

*Balducci, C., Schaufeli, W. B., \& Fraccaroli, F. 2011. The job demands-resources model and counterproductive work behaviour: The role of job-related affect. European Journal of Work and Organizational Psychology, 20: 467-496.

*Bamford, M., Wong, C.A., \& Laschinger, H. 2013. The influence of authentic leadership and areas of work-life on work engagement of registered nurses. Journal of Nursing Management, 21: 529-540.

Banks, M. 2006. How one federal agency harnessed employee engagement as a tool for transformation. Journal of Organizational Excellence, 25: 21-30.

Bargagliotti, L. A. 2012. Work engagement in nursing: A concept analysis. Journal of Advanced Nursing, 68: 1414-1428.

*Biggs, A., Brough, P., \& Barbour, J. P. 2014. Strategic alignment with organizational priorities and work engagement: A multi-wave analysis. Journal of Organizational Behavior, 35: 301-317.

Briner, R. B., 2011. Systematic Review and Evidence Synthesis as a Practice and Scholarship. Oxford Handbook of Evidence-Based Management. Oxford: Oxford University Press.

Briner, R. B. 2014. What is employee engagement and does it matter? An evidence-based approach. In D. Robinson and J. Gifford (Eds), The future of engagement thought piece collection,. Engage for Success peer-reviewed thought leadership series, London: Engage for Success. http://engageforsuccess.org/the-future-of-employee-engagement.

Briner, R. B., \& Denyer, D. 2010. Systematic review and evidence synthesis as a practice and scholarship tool, in Rousseau, D. (Ed.), Handbook of evidence-based management: Companies, classrooms, and research. Oxford University Press. Retrieved September 2013, from http://www.cebma.org/wp-content/uploads/Briner-Denyer-Systematic-Review-EvidenceSynthesis.pdf

Brown, K. 2004. Human resource management in the public sector. Public Management Review, 6: 303-309.

Brown, A. D., \& Humphreys, M. 1995. International cultural differences in public sector management: Lessons from a survey of British and Egyptian technical education managers. International Journal of Public Sector Management, 8(3): 5-23.

*Brunetto, Y., Teo, S. T., Shacklock, K., \& Farr-Wharton, R. 2012. Emotional intelligence, job satisfaction, well-being and engagement: explaining organisational commitment and turnover intentions in policing. Human Resource Management Journal, 22: 428-441.

Cabinet Office 2015. Civil Service People Survey: 2015 Results. London: Cabinet Office. https://www.gov.uk/government/publications/civil-service-people-survey-2015-results

Capell, B., Kubra Canhilal, S., Alas, R., Sommer, L., \& Ossenkop, C. 2013. Mapping values in old vs new members of the European Union: A comparative analysis of public sector cultures. Cross Cultural Management, 20: 503-527. 
*Cogin, J. A., \& Fish, A. 2009. An empirical investigation of sexual harassment and work engagement: Surprising differences between men and women. Journal of Management \& Organization, 15: 47-61.

Crawford, E. R., LePine, J. A., \& Rich, B. L. 2010. Linking job demands and resources to employee engagement and burnout: a theoretical extension and meta-analytic test. Journal of Applied Psychology, 95: 834-848.

*del Líbano, M., Llorens, S., Salanova, M., \& Schaufeli, W. B. 2012. About the dark and bright sides of self-efficacy: Workaholism and work engagement. The Spanish journal of Psychology, 15: 688-701.

*Forbes, G., Freeman, R., Mccombes, W., \& Humphris, G. 2013. Job leaving intentions and occupation-related beliefs amongst preregistered dental nurses in Scotland: The mediating role of work engagement and personal accomplishment. Community Dentistry and Oral Epidemiology, 42: 11-19.

Fredrickson, B. L. 2001. The role of positive emotions in positive psychology: The broaden-andbuild theory of positive emotions. American Psychologist, 56: 218-226.

*Freeney, Y., \& Fellenz, M. R. 2013. Work engagement as a key driver of quality of care: A study with midwives. Journal of Health, Organisation and Management, 27: 330-349.

*Gillet, N., Fouquereau, E., Bonnaud-Antignac, A., Mokounkolo, R., \& Colombat, P. 2013. The mediating role of organizational justice in the relationship between transformational leadership and nurses' quality of work life: A cross-sectional questionnaire survey. International Journal of Nursing Studies, 50: 1359-1367.

*Glasø, L., Bele, E., Nielsen, M. B., \& Einarsen, S. 2011. Bus drivers' exposure to bullying at work: An occupation-specific approach. Scandinavian Journal of Psychology, 52: 484-493.

*Gorter, R. C., \& Freeman, R. 2011. Burnout and engagement in relation with job demands and resources among dental staff in Northern Ireland. Community Dentistry and Oral Epidemiology, 39: 87-95.

Green, F. 2001. It's been a hard day's night: the concentration and intensification of work in late twentieth-century Britain. British Journal of Industrial Relations, 39: 53-80.

Green, F. 2004. Why has work effort become more intense?. Industrial Relations: A Journal of Economy and Society, 43: 709-741.

Guest, D. 2014. Employee engagement: A sceptical analysis. Journal of Organizational Effectiveness: People and Performance, 1: 141-156.

*Hakanen, J. J., \& Schaufeli, W. B. 2012. Do burnout and work engagement predict depressive symptoms and life satisfaction? A three-wave seven-year prospective study. Journal of Affective Disorders, 141: 415-424.

*Hakanen, J. J., Bakker, A. B., \& Demerouti, E. 2005. How dentists cope with their job demands and stay engaged: The moderating role of job resources. European Journal of Oral Sciences, 113: 479-487. 
*Høigaard, R., Giske, R., \& Sundsli, K. 2012. Newly qualified teachers' work engagement and teacher efficacy influences on job satisfaction, burnout, and the intention to quit. European Journal of Teacher Education, 35: 347-357.

Hobfoll, S. E. 1989. Conservation of resources: A new attempt at conceptualizing stress. American Psychologist, 44: 513-524.

*Hornung, S., Rousseau, D.M., Glaser, J., Angerer, P., \& Weigl, M. 2010. Beyond top-down and bottom-up work redesign: Customizing job content through idiosyncratic deals. Journal of Organizational Behavior, 31: 187-215.

*Hornung, S., Glaser, J., Rousseau, D. M., Angerer, P., \& Weigl, M. 2011. Employee-oriented leadership and quality of working life: Mediating roles of idiosyncratic deals. Psychological Reports, 108: 59-74.

*Hu, Q., Schaufeli, W. B., \& Taris, T. W. 2011. The job demands-resources model: An analysis of additive and joint effects of demands and resources. Journal of Vocational Behavior, 79: 181190.

Kahn, W., 1990. Psychological conditions of personal engagement and disengagement at work. Academy of Management Journal, 33: 692-724.

Kim, P. S. 1999. Globalization of human resource management: A cross-cultural perspective for the public sector. Public Personnel Management, 28: 227-243.

*Klassen, R. M., Aldhafri, S., Mansfield, C. F., Purwanto, E., Siu, A. F., Wong, M. W., \& WoodsMcConney, A. 2012. Teachers' engagement at work: An international validation study. The Journal of Experimental Education, 80: 317-337.

Korunga, C., Scharitzer, D., Carayons, P., \& Sainfort, F. 2003. Employee strain and job satisfaction related to an implementation of quality in a public service organization: A longitudinal study', Work and Stress, 17: 52-72.

Kuipers, B. S., Higgs, M., Kickert, W., Tummers, L., Grandia, J., \& Van der Voet, J. 2014. The management of change in public organizations: A literature review. Public Administration, 92: 120 .

*Kühnel, J., \& Sonnentag, S. 2011. How long do you benefit from vacation? A closer look at the fade-out of vacation effects. Journal of Organizational Behavior, 32: 125-143.

*Mauno, S., Kinnunen, U., \& Ruokolainen, M. 2007. Job demands and resources as antecedents of work engagement: A longitudinal study. Journal of Vocational Behavior, 70: 149-171.

*Mauno, S., Kinnunen, U., Mäkikangas, A., \& Nätti, J. 2005. Psychological consequences of fixed-term employment and perceived job insecurity among health care staff. European Journal of Work and Organizational Psychology, 14: 209-237.

*Opie, T., Lenthall, S., Wakerman, J., Dollard, M., Macleod, M., Knight, S., Rickard, G., \& Dunn, S. 2011. Occupational stress in the Australian nursing workforce: A comparison between hospitalbased nurses and nurses working in very remote communities. Australian Journal of Advanced Nursing, 28(4): 36-43.

Osborne, S. P., Radnor, Z., Vidal, I., \& Kinder, T. 2014. A sustainable business model for public service organizations?. Public Management Review, 16: 165-172. 
*Othman, N., \& Nasurdin, A.M. 2012. Social support and work engagement: A study of Malaysian nurses. Journal of Nursing Management, 21: 1083-1090.

*Ouweneel, E., Le Blanc, P. M., \& Schaufeli, W. B. 2012. Don't leave your heart at home: Gain cycles of positive emotions, resources, and engagement at work. Career Development International, 17: 537-556.

*Ouweneel, E., Le Blanc, P. M., Schaufeli, W. B., \& van Wijhe, C. I. 2012. Good morning, good day: A diary study on positive emotions, hope, and work engagement. Human Relations, 65: $1129-1154$.

NHS (2015). NHS Staff Survey 2015. Oxford, UK: Picker Institute Europe. http://www.nhsstaffsurveys.com/Page/1010/Home/NHS-Staff-Survey-2015/

NHS Employers (2015). Staff Engagement. Leeds, UK: NHS Employers. http://www.nhsemployers.org/your-workforce/retain-and-improve/staff-experience/staffengagement

*Poulsen, M. G., Poulsen, A. A., Khan, A., Poulsen, E. E., \& Khan, S. R. 2012. Factors associated with subjective well-being in cancer workers in Queensland. Journal of Medical Imaging and Radiation Oncology, 56: 347-353.

Purcell, J. 2014. Disengaging from engagement. Human Resource Management Journal, 24 : 241-254.

*Ratnasingam, P., Spitzmueller, C., King, W. R., Rubino, C., Luksyte, A., Matthews, R. A., \& Fisher, G. G. 2012. Can on-site childcare have detrimental work outcomes? Examining the moderating roles of family supportive organization perceptions and childcare satisfaction. Journal of Occupational Health Psychology, 17: 435-444.

*Reissner, S., \& Pagan, V. 2013. Generating employee engagement in a public-private partnership: management communication activities and employee experiences. The International Journal of Human Resource Management, 24: 2741-2759.

*Rich, B. L., Lepine, J. A., \& Crawford, E. R. 2010. Job engagement: Antecedents and effects on job performance. Academy of Management Journal, 53: 617-635.

*Rickard, G., Lenthall, S., Dollard, M., Opie, T., Knight, S., Dunn, S., Wakerman, J., Macleod, M., Seiler, J., \& Brewster-Webb, D. 2012. Organisational intervention to reduce occupational stress and turnover in hospital nurses in the Northern Territory, Australia. Collegian, 19: 211-221.

Rothmann, S. 2014. Employee engagement in a cultural context In C.Truss et al., (Eds.) Employee Engagement in Theory and Practice: 163-179. London: Routledge.

Saks, A. M. 2006. Antecedents and consequences of employee engagement. Journal of Managerial Psychology, 21: 600-619.

Schaufeli, W. B. 2014. What is Engagement? In. C.Truss et al., (Eds) Employee Engagement in Theory and Practice: 15-35. London: Routledge.

Schaufeli, W. B., \& Bakker, A. B. 2003. Utrecht Work Engagement Scale: Preliminary Manual. Occupational Health Psychology Unit, Utrecht University, Utrecht, Netherlands. 
Schaufeli W. B., Salanova M, González-Romá V, \& Bakker A. B. 2002. The measurement of engagement and burnout: A two sample confirmatory factor analytic approach. Journal of Happiness Studies, 3: 71-92.

*Selmer, J., Jonasson, C., \& Lauring, J. 2013. Group conflict and faculty engagement: Is there a moderating effect of group trust?. Journal of Higher Education Policy and Management, 35: 95109.

*Simbula, S. 2010. Daily fluctuations in teachers' well-being: a diary study using the job demandsresources model. Anxiety, Stress, \& Coping, 23: 563-584.

*Spence Laschinger, H. K. 2010. Staff nurse work engagement in Canadian hospital settings: The influence of workplace empowerment and six areas of worklife. In S. Albrecht (Ed.), Handbook of Employee Engagement: Perspectives, Issues, Research and Practice: 309-322. Cheltenham, UK: Edward Elgar.

*Spence Laschinger, H. K. 2012. Job and career satisfaction and turnover intentions of newly graduated nurses. Journal of Nursing Management, 20: 472-484.

*Spence Laschinger, H. K., Grau, A. L., Finegan, J., \& Wilk, P. 2012. Predictors of new graduate nurses' workplace well-being: Testing the job demands-resources model. Health Care Management Review, 37: 175-186.

*Spence Laschinger, H. K., Wilk, P., Cho, J., \& Greco, P. 2009. Empowerment, engagement and perceived effectiveness in nursing work environments: Does experience matter? Journal of Nursing Management, 17: 636-646.

*Sulea, C., Virga, D., Maricutoiu, L. P., Schaufeli, W. B., Zaborila Dumitru, C., \& Sava, F. A. 2012. Work engagement as mediator between job characteristics and positive and negative extrarole behaviors. Career Development International, 17: 188-207.

*Taipale, S., Selander, K., Anttila, T., \& Natti, J. 2011. Work engagement in eight European countries: The role of job demands, autonomy, and social support. International Journal of Sociology and Social Policy, 31: 486-504.

*Tanner, C., Brügger, A., van Schie, S., \& Lebherz, C. 2010. Actions speak louder than words. Zeitschrift für Psychologie/Journal of Psychology, 218: 225-233.

US Department of Health and Human Services (2015). Annual Performance Plan and Report: Goal 4. Objective C: Invest in the HHS Workforce to Help Meet America's Health and Human Service Needs. Washing D.C: US Department of Health and Human Services. http://www.hhs.gov/budget/performance/2016/annual-performance-plan-report-goal-4-objectivec.html

*Van Beek, I., Hu, Q., Schaufeli, W. B., Taris, T. W., \& Schreurs, B. H. J. 2012. For fun, love, or money: What drives workaholic, engaged, and burned-out employees at work? Applied Psychology: An International Review, 61: 30-55.

*Van Bogaert, P., Clarke, S., Willems, R., \& Mondelaers, M. 2013. Staff engagement as a target for managing work environments in psychiatric hospitals: Implications for workforce stability and quality of care. Journal of Clinical Nursing, 22: 1717-1728.

*Van Den Broeck, A., Van Ruysseveldt, J., Smulders, P., \& De Witte, H. 2011. Does an intrinsic work value orientation strengthen the impact of job resources? A perspective from the Job 
Demands-Resources Model. European Journal of Work and Organizational Psychology, 20: 581-609.

Vandenabeele, W., Brewer, G. A., \& Ritz, A. 2014. Past, present, and future of public service motivation research. Public Administration, 92: 779-789.

*Vera, M., Salanova, M., \& Martín, B. 2010. University faculty and work-related well-being: The importance of the triple work profile. Electronic Journal of Research in Educational Psychology, 8: 581-602.

Viera A. J., \& Garrett, J. M. 2005. Understanding inter-observer agreement: The kappa statistic. (Family Medicine) Research Series, 37: 360-363.

*Vogelgesang, G. R., Leroy, H., \& Avolio, B. J. 2013. The mediating effects of leader integrity with transparency in communication and work engagement/performance. The Leadership Quarterly, 24: 405-413.

*Weigl, M., Hornung, S., Parker, S. K., Petru, R., Glaser, J., \& Angerer, P. 2010. Work engagement accumulation of task, social, personal resources: A three-wave structural equation model. Journal of Vocational Behavior, 77: 140-153.

*Wong, C. A., Spence Laschinger, H. K., \& Cummings, G.G. 2010. Authentic leadership and nurses' voice behaviour and perceptions of care quality. Journal of Nursing Management, 18: 889-900.

Zeytinoglu, I. U., Denton, M., Davies, S., Baumann, A., Blythe, J., \& Boos, L. 2007. Associations between work intensification, stress and job satisfaction: The case of nurses in Ontario. Relations Industrielles/Industrial Relations, 62: 201-225. 
Table 1. Overview of the methodological and theoretical characteristics of the included studies

\begin{tabular}{|lll|}
\hline Methodological/Theoretical Characteristic & Count & Percentage \\
\hline Research design & & \\
Cross-sectional, mainly self-report & 41 & 69.4 \\
Multilevel & 7 & 11.9 \\
Time-lagged/longitudinal & 7 & 11.9 \\
Intervention & 2 & 3.4 \\
Qualitative & 2 & 3.4 \\
Total & 59 & 100.0 \\
Sample characteristics & & \\
Healthcare & 27 & 45.7 \\
Public education & 13 & 22.0 \\
Emergency service & 9 & 15.3 \\
General government/mixed & 9 & 15.3 \\
Military & 1 & 1.7 \\
Total & 59 & 100.0 \\
Geographical location & & \\
Continental Europe & 17 & 28.8 \\
North America & 11 & 18.6 \\
Nordic Countries & 9 & 15.3 \\
Australia/New Zealand & 7 & 11.9 \\
Southern/Central Europe & 5 & 8.4 \\
UK/Ireland & 4 & 6.8 \\
China & 2 & 3.4 \\
International & 2 & 3.4 \\
Other & 2 & 3.4 \\
Total & 59 & 100.0 \\
Definitions/measures & & \\
Work engagement (based on Schaufeli et al., 2002) & 52 & 88.1 \\
Multidimensional engagement (based on Saks, 2006) & 3 & 5.1 \\
Personal role engagement (based on Kahn, 1990) & 2 & 3.4 \\
Engagement as management practice & 2 & 3.4 \\
Total & 59 & 100.0 \\
Theoretical foundations & & \\
Job demands-resources & 26 & 44.1 \\
Conservation of resources & 5 & 8.4 \\
Self-determination/self-efficacy & 5 & 8.4 \\
Social exchange & 4 & 6.8 \\
Broaden-and-build & 4 & 6.8 \\
Leadership & 4 & 6.8 \\
Other theories & 4 & 6.8 \\
No specific theory & 71.9 \\
Total & 59 & 100.0 \\
\hline
\end{tabular}


Table 2. Findings of the 59 studies examining engagement within the public sector

\begin{tabular}{|c|c|c|c|c|}
\hline $\begin{array}{l}\text { Author/date/ } \\
\text { Location }\end{array}$ & Study population & Antecedents & Morale Outcomes & Performance Outcomes \\
\hline $\begin{array}{l}\text { Abdelhadi and } \\
\text { Drach-Zahavy } \\
\text { (2012) Israel }\end{array}$ & $\begin{array}{l}158 \text { nurses in } 40 \text { retirement } \\
\text { home wards }\end{array}$ & + association with service climate & & $\begin{array}{l}+ \text { association with patient } \\
\text { centred care. Engagement } \\
\text { mediated relationship between } \\
\text { service climate and patient } \\
\text { centred care. }\end{array}$ \\
\hline $\begin{array}{l}\text { Adriaenssens et al. } \\
\text { (2011) Belgium }\end{array}$ & $\begin{array}{l}254 \text { emergency nurses } \\
\text { based in } 40 \text { wards and } 699 \\
\text { general nurses. }\end{array}$ & $\begin{array}{l}+ \text { association with work characteristics, } \\
\text { particularly skill discretion, supervisory } \\
\text { support, work procedures, and rewards. }\end{array}$ & & \\
\hline $\begin{array}{l}\text { Airila et al. (2012) } \\
\text { Finland }\end{array}$ & 403 Finnish Firefighters & & $\begin{array}{l}+ \text { association with three sub- } \\
\text { dimensions of work ability (current } \\
\text { work ability generally, in relation to } \\
\text { job demands, psychological } \\
\text { resources), but not associated with } \\
\text { the other three sub-dimensions of } \\
\text { work ability (diseases, sick leaves, } \\
\text { own prognosis of work ability) }\end{array}$ & \\
\hline $\begin{array}{l}\text { Anaza and } \\
\text { Rutherford } \\
(2012 a) \text { USA }\end{array}$ & $\begin{array}{l}297 \text { employees from a co- } \\
\text { operative extension system, } \\
74 \% \text { female }\end{array}$ & $\begin{array}{l}+ \text { association with organizational } \\
\text { identification, employee-customer } \\
\text { identification and customer orientation. } \\
\text { Impact of organizational identification } \\
\text { and employee-customer identification } \\
\text { was mediated by customer orientation. }\end{array}$ & & \\
\hline $\begin{array}{l}\text { Anaza and } \\
\text { Rutherford } \\
(2012 b) \text { USA }\end{array}$ & $\begin{array}{l}272 \text { front line employees } \\
\text { from a co-operative } \\
\text { extension system }\end{array}$ & $\begin{array}{l}+ \text { association with internal marketing, and } \\
\text { employee patronage. Employee } \\
\text { patronage mediated the relationships } \\
\text { between internal marketing and } \\
\text { engagement. }\end{array}$ & & \\
\hline
\end{tabular}




\begin{tabular}{|c|c|c|c|c|}
\hline $\begin{array}{l}\text { Author/date/ } \\
\text { Location }\end{array}$ & Study population & Antecedents & Morale Outcomes & Performance Outcomes \\
\hline $\begin{array}{l}\text { Arrowsmith and } \\
\text { Parker (2013) } \\
\text { New Zealand }\end{array}$ & $\begin{array}{l}\text { Case study of a HR change } \\
\text { initiative at the NZ Post } \\
\text { between } 2009-11 \text { involving } \\
12 \text { informants }\end{array}$ & $\begin{array}{l}\text { Implementation of engagement initiatives } \\
\text { requires political astuteness and } \\
\text { commitment of HR professionals. } \\
\text { Requirement for a business case for } \\
\text { engagement focused on performance. } \\
\text { Engagement requires focus on voice, } \\
\text { work design and management agency. }\end{array}$ & & \\
\hline $\begin{array}{l}\text { Bakker and } \mathrm{Bal} \\
(2010) \\
\text { Netherlands }\end{array}$ & $\begin{array}{l}54 \text { Dutch primary school } \\
\text { teachers, who were } \\
\text { completing teacher training }\end{array}$ & $\begin{array}{l}\text { + association, at week-level, with weekly } \\
\text { autonomy, supervisory exchange } \\
\text { (coaching and feedback) and } \\
\text { opportunities for development. } \\
\text { Reciprocal effects found. No significant } \\
\text { association, at week-level, with weekly } \\
\text { social support. }\end{array}$ & & $\begin{array}{l}+ \text { association, at week-level, } \\
\text { with weekly job performance. } \\
\text { Engagement, at week-level, } \\
\text { mediated the relationship } \\
\text { between weekly autonomy/ } \\
\text { opportunities for development } \\
\text { and weekly job performance. }\end{array}$ \\
\hline $\begin{array}{l}\text { Bakker and } \\
\text { Xanthopoulou } \\
\text { (2013) } \\
\text { Netherlands }\end{array}$ & $\begin{array}{l}84 \text { female school principals } \\
\text { and } 190 \text { teachers }\end{array}$ & $\begin{array}{l}+ \text { association with job resources } \\
\text { (autonomy, social support, performance } \\
\text { feedback, professional development) and } \\
\text { personal resources (self-efficacy, } \\
\text { resilience). Personal resources mediated } \\
\text { the relationship between job resources } \\
\text { and engagement. }\end{array}$ & & $\begin{array}{l}+ \text { association with principal's } \\
\text { creativity. Engagement mediated } \\
\text { the relationship between } \\
\text { job/personal resources and } \\
\text { creativity. }\end{array}$ \\
\hline 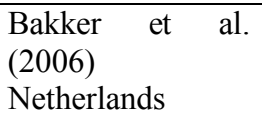 & $\begin{array}{l}2,229 \text { constabulary officers } \\
\text { in } 85 \text { teams }\end{array}$ & $\begin{array}{l}+ \text { association between team level } \\
\text { engagement and all three individual level } \\
\text { engagement facets }\end{array}$ & & \\
\hline $\begin{array}{l}\text { Bakker et al. } \\
\text { (2007) Finland }\end{array}$ & $\begin{array}{l}805 \text { Finnish teachers, with } \\
\text { majority teaching in } \\
\text { primary/lower secondary } \\
\text { schools. }\end{array}$ & $\begin{array}{l}\text { - association with pupil misbehavior and } \\
\text { engagement, moderated by supervisor } \\
\text { support, organizational climate, } \\
\text { innovativeness and appreciation. } \\
\text { Information had a moderator effect on the } \\
\text { relationship between pupil misbehavior } \\
\text { and vigor and absorption. }\end{array}$ & & \\
\hline
\end{tabular}




\begin{tabular}{|c|c|c|c|c|}
\hline $\begin{array}{l}\text { Author/date/ } \\
\text { Location }\end{array}$ & Study population & Antecedents & Morale Outcomes & Performance Outcomes \\
\hline $\begin{array}{l}\text { Bal and Kooij } \\
\text { (2011) } \\
\text { Netherlands }\end{array}$ & $\begin{array}{l}465 \text { healthcare employees; } \\
73 \% \text { female }\end{array}$ & $\begin{array}{l}\text { - association with transactional } \\
\text { psychological contract and + association } \\
\text { with relational psychological contract. } \\
\text { Psychological contracts mediated the } \\
\text { association between work centrality and } \\
\text { engagement. }\end{array}$ & & \\
\hline $\begin{array}{l}\text { Bal et al. (2013) } \\
\text { Netherlands }\end{array}$ & $\begin{array}{l}1,058 \quad \text { healthcare } \\
\text { employees; } 77 \% \text { female; } \\
74 \% \text { part-time workers }\end{array}$ & $\begin{array}{l}+ \text { association with developmental HRM } \\
\text { and engagement. Relationship mediated } \\
\text { by psychological contract. - association } \\
\text { with accommodative HRM for those low } \\
\text { in selection, optimisation and } \\
\text { compensation strategies }\end{array}$ & & \\
\hline $\begin{array}{l}\text { Balducci et al. } \\
\text { (2011) Italy }\end{array}$ & $\begin{array}{lll}818 \quad \text { public } & \text { sector } \\
\text { employees } & \end{array}$ & $\begin{array}{l}+ \text { association with job resources } \\
\text { (consisting of autonomy, promotion } \\
\text { prospects, social support) and with } \\
\text { positive affect. Positive affect mediated } \\
\text { the link between job resources and } \\
\text { engagement. }\end{array}$ & & \\
\hline $\begin{array}{l}\text { Bamford et al. } \\
\text { (2013) Canada }\end{array}$ & 280 nurses in acute care & $\begin{array}{l}\text { + association with areas of work life } \\
\text { (workload, control, rewards, community, } \\
\text { fairness, values) and with authentic } \\
\text { leadership. Areas of worklife mediated } \\
\text { the link between authentic leadership and } \\
\text { engagement. }\end{array}$ & & \\
\hline $\begin{array}{l}\text { Biggs et al. (2013) } \\
\text { Australia }\end{array}$ & $\begin{array}{l}1011 \text { employees of state } \\
\text { police service }\end{array}$ & $\begin{array}{l}+ \text { association with work alignment. } \\
\text { Reciprocal relationships between } \\
\text { strategic alignment, job control and } \\
\text { engagement. }\end{array}$ & & \\
\hline $\begin{array}{l}\text { Brunetto et al. } \\
\text { (2012) Australia }\end{array}$ & $\begin{array}{l}193 \text { police officers. } \\
\text { Majority male and with low } \\
\text { tenure }\end{array}$ & & $\begin{array}{l}+ \text { association with organizational } \\
\text { commitment }- \text { association with } \\
\text { turnover intentions }\end{array}$ & \\
\hline $\begin{array}{l}\text { Cogin and Fish } \\
\text { (2009) Australia }\end{array}$ & $\begin{array}{l}538 \text { nurses in eight } \\
\text { hospitals; nearly half were } \\
\text { student nurses with } \\
\text { minimum of } 6 \text {-months } \\
\text { training }\end{array}$ & $\begin{array}{l}\text { - association with each dimension of } \\
\text { sexual harassment (gender harassment; } \\
\text { unwanted sexual attention; sexual } \\
\text { coercion). }\end{array}$ & & \\
\hline
\end{tabular}




\begin{tabular}{|c|c|c|c|c|}
\hline $\begin{array}{l}\text { Author/date/ } \\
\text { Location }\end{array}$ & Study population & Antecedents & Morale Outcomes & Performance Outcomes \\
\hline $\begin{array}{l}\text { Del Libano et al. } \\
\text { (2012) Spain }\end{array}$ & $\begin{array}{l}386 \quad \text { University } \\
\text { administrative staff }\end{array}$ & + association with self-efficacy & $\begin{array}{l}+ \text { association with job satisfaction } \\
\text { and organizational commitment }\end{array}$ & \\
\hline $\begin{array}{l}\text { Forbes et al. } \\
\text { (2013) Scotland }\end{array}$ & $\begin{array}{l}231 \text { pre-registered dental } \\
\text { nurses in } 10 \text { educational } \\
\text { locations. All female. }\end{array}$ & + association with job resource beliefs & - association with intention to leave & \\
\hline $\begin{array}{lr}\text { Freeney } & \text { and } \\
\text { Fellenz } & (2013) \\
\text { Ireland } & \end{array}$ & $\begin{array}{l}158 \text { midwives from two } \\
\text { large maternity hospitals, } \\
98 \% \text { female }\end{array}$ & $\begin{array}{l}\text { + association with organizational support, } \\
\text { supervisor support, and social support. }\end{array}$ & + association with general health & $\begin{array}{l}+ \text { association with quality of } \\
\text { care. Engagement mediated the } \\
\text { relationships between } \\
\text { organizational/supervisor/social } \\
\text { support and quality of care. }\end{array}$ \\
\hline $\begin{array}{l}\text { Gillet et al. (2013) } \\
\text { France }\end{array}$ & $\begin{array}{l}\text { Study 1: } 235 \text { policemen }(62 \\
\text { female) Study 2: } 147 \\
\text { policemen (of whom } 32 \\
\text { female) }\end{array}$ & $\begin{array}{l}\text { Study 1: + association with global } \\
\text { motivation, perceived organizational } \\
\text { support, and contextual motivation. Study } \\
2:++ \text { association with contextual } \\
\text { motivation, perceived supervisor support, } \\
\text { and situational motivation. }\end{array}$ & & \\
\hline $\begin{array}{l}\text { Glaso et al. (2011) } \\
\text { Norway }\end{array}$ & $\begin{array}{l}1,023 \text { bus drivers, } 87 \% \\
\text { male }\end{array}$ & $\begin{array}{l}\text { - association with exposure to harassment } \\
\text { and bullying. }\end{array}$ & & \\
\hline $\begin{array}{l}\text { Gorter and } \\
\text { Freeman (2011) } \\
\text { Northern Ireland }\end{array}$ & $\begin{array}{l}71 \text { dentists }(37 \% \text { female }) \\
\text { and } 64 \text { dental care } \\
\text { practitioners (all women). }\end{array}$ & $\begin{array}{l}\text { Joy of manual-technical work and } \\
\text { treatment of results }+ \text { associated with two } \\
\text { dimensions of engagement. }\end{array}$ & & \\
\hline $\begin{array}{lr}\text { Hakanen } & \text { and } \\
\text { Schaufeli } & (2012) \\
\text { Finland } & \end{array}$ & 1964 dentists & & 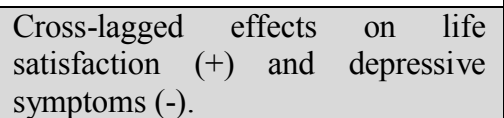 & \\
\hline $\begin{array}{l}\text { Hakanen et al. } \\
\text { (2005) Finland }\end{array}$ & 1919 dentists, $77 \%$ female & $\begin{array}{l}\text { - association with job demands } \\
\text { (qualitative workload, physical } \\
\text { environment, emotional dissonance, } \\
\text { negative impact of dental law reforms). + } \\
\text { association with job resources (job } \\
\text { control, innovativeness, variability of } \\
\text { skill, peer contacts, positive patient } \\
\text { outcomes). Job resources were more } \\
\text { strongly associated with engagement than } \\
\text { job demands. Job resources most salient } \\
\text { when job demands were high. }\end{array}$ & & \\
\hline
\end{tabular}




\begin{tabular}{|c|c|c|c|c|}
\hline $\begin{array}{l}\text { Author/date/ } \\
\text { Location }\end{array}$ & Study population & Antecedents & Morale Outcomes & Performance Outcomes \\
\hline $\begin{array}{l}\text { Hoigaard et al. } \\
\text { (2012) Norway }\end{array}$ & $\begin{array}{l}191 \text { teachers with less than } \\
6 \text { years' experience }\end{array}$ & & $\begin{array}{l}\text { When personal efficacy was } \\
\text { controlled for, only dedication (not } \\
\text { vigor or absorption) dimension of } \\
\text { engagement was }+ \text { associated with } \\
\text { job satisfaction, and absorption (not } \\
\text { vigor or dedication) was + } \\
\text { associated with emotional } \\
\text { exhaustion and }+ \text { associated with } \\
\text { turnover intentions. }\end{array}$ & \\
\hline $\begin{array}{l}\text { Hornung et al. } \\
\text { (2010) Germany }\end{array}$ & $\begin{array}{l}292 \text { physicians; } 68 \% \\
\text { female }\end{array}$ & $\begin{array}{l}\text { + association with work complexity and } \\
\text { control, and - association with hindrances. } \\
+ \text { association of task idiosyncratic deals. } \\
\text { Work complexity, control, and hindrances } \\
\text { mediated the relationship between task } \\
\text { idiosyncratic deals and engagement. }\end{array}$ & & \\
\hline $\begin{array}{l}\text { Hornung et al. } \\
\text { (2011) Germany }\end{array}$ & $\begin{array}{l}\text { Medical doctors; } 1^{\text {st }} \text { wave: } \\
\mathrm{N}=159 ; 46.5 \% \text { female; } 2^{\text {nd }} \\
\text { Wave: } \quad \mathrm{N}=142 ; \quad 48.6 \% \\
\text { female }\end{array}$ & $\begin{array}{l}+ \text { association with development } \\
\text { idiosyncratic deals and with leader } \\
\text { consideration. No association with } \\
\text { flexibility idiosyncratic deals. } \\
\text { Development deals mediated the } \\
\text { relationship between leader consideration } \\
\text { and engagement }\end{array}$ & & \\
\hline $\begin{array}{l}\text { Hu et al. (2011) } \\
\text { China }\end{array}$ & $\begin{array}{l}625 \text { blue collar workers and } \\
761 \text { health professionals }\end{array}$ & $\begin{array}{l}+ \text { association with job resources } \\
\text { (consisting of job control, colleague } \\
\text { support, supervisory coaching, learning } \\
\text { opportunities, task clarity). - association } \\
\text { with job demands (consisting of } \\
\text { workload, emotional demands, physical } \\
\text { effort, interpersonal conflict) Synergistic } \\
\text { effects: high job demands and low job } \\
\text { resources were associated with lower } \\
\text { engagement }\end{array}$ & $\begin{array}{l}+ \text { association with organizational } \\
\text { commitment }- \text { association with } \\
\text { turnover intentions }\end{array}$ & \\
\hline
\end{tabular}




\begin{tabular}{|c|c|c|c|c|}
\hline $\begin{array}{l}\text { Author/date/ } \\
\text { Location }\end{array}$ & Study population & Antecedents & Morale Outcomes & Performance Outcomes \\
\hline 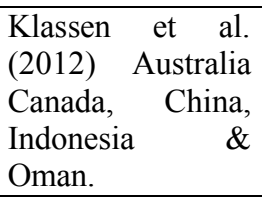 & $\begin{array}{l}853 \text { teachers. Majority } \\
\text { female. }\end{array}$ & & $\begin{array}{l}+ \text { association with job satisfaction. - } \\
\text { association with turnover intention. }\end{array}$ & \\
\hline $\begin{array}{l}\text { Kühnel and } \\
\text { Sonnentag (2011) } \\
\text { Germany }\end{array}$ & 131 teachers. $69 \%$ female & $\begin{array}{l}+ \text { effect of vacation, with this fading over } \\
\text { time. Time pressure and pupil misconduct } \\
\text { not related to fade-out of engagement. } \\
\text { Relaxation experiences related to fade-out } \\
\text { of engagement, but became non- } \\
\text { significant over time. }\end{array}$ & & \\
\hline $\begin{array}{l}\text { Mauno et al. } \\
\text { (2005) Finland }\end{array}$ & $\begin{array}{l}727 \text { public sector workers } \\
\text { in one hospital district. } \\
\text { Nursing staff comprised } \\
64 \% \text { of the sample. }\end{array}$ & $\begin{array}{l}\text { association with perceived job } \\
\text { insecurity Those on fixed term contracts } \\
\text { were more highly engaged than those on } \\
\text { permanent contracts. Under conditions of } \\
\text { a high level of job insecurity those who } \\
\text { had a permanent job reported a lower } \\
\text { level of work engagement than those with } \\
\text { a fixed-term job, whereas under } \\
\text { conditions of low job insecurity, job } \\
\text { contract did not matter }\end{array}$ & & \\
\hline $\begin{array}{l}\text { Mauno et al. } \\
\text { (2007) Finland }\end{array}$ & $\begin{array}{l}409 \text { healthcare employees } \\
(735 \text { at time } 1), \quad 87 \% \\
\text { women }\end{array}$ & $\begin{array}{l}\text { + association of job resources (consisting } \\
\text { of organizational-based self esteem and } \\
\text { job control). - association with job } \\
\text { demands (consisting of job insecurity, } \\
\text { work-to-family conflict, time demands). } \\
\text { After controlling for the baseline level of } \\
\text { engagement most of the relationships } \\
\text { between job resources/demands and later } \\
\text { engagement disappeared. }\end{array}$ & & \\
\hline $\begin{array}{l}\text { Opie et al. (2011) } \\
\text { Australia }\end{array}$ & $\begin{array}{l}349 \text { nurses working in very } \\
\text { remote location and } 277 \\
\text { nurses working in three } \\
\text { major hospitals (mainly } \\
\text { females) }\end{array}$ & $\begin{array}{l}\text { Nurses working very } \\
\text { demonstrated higher levels of work } \\
\text { engagement. + association with job } \\
\text { control, possibilities for development, } \\
\text { and opportunity for professional } \\
\text { development. }\end{array}$ & & \\
\hline
\end{tabular}




\begin{tabular}{|c|c|c|c|c|}
\hline $\begin{array}{l}\text { Author/date/ } \\
\text { Location }\end{array}$ & Study population & Antecedents & Morale Outcomes & Performance Outcomes \\
\hline $\begin{array}{lr}\text { Othman } & \text { and } \\
\text { Nasurdin } & (2012) \\
\text { Malaysia } & \\
\end{array}$ & 402 nurses; $98.5 \%$ female & $\begin{array}{l}+ \text { association with supervisor support and } \\
\text { co-worker support. }\end{array}$ & & \\
\hline $\begin{array}{l}\text { Ouweneel et al. } \\
(2012 a) \\
\text { Netherlands }\end{array}$ & 200 University employees & $\begin{array}{l}\text { + lagged effects of personal resources } \\
\text { (consisting of hope, optimism and self- } \\
\text { efficacy). No significant lagged effects of } \\
\text { job resources (consisting of supervisory } \\
\text { coaching, autonomy, opportunities for } \\
\text { development). }\end{array}$ & & \\
\hline $\begin{array}{l}\text { Ouweneel et al. } \\
(2012 b) \\
\text { Netherlands }\end{array}$ & $\begin{array}{l}59 \text { University employees } \\
\text { (mainly female) }\end{array}$ & $\begin{array}{l}+ \text { association, at day-level, with positive } \\
\text { emotions after work the day before and } \\
\text { hope before work the same day. Hope } \\
\text { mediated relationship between positive } \\
\text { emotions and engagement. }\end{array}$ & & \\
\hline $\begin{array}{l}\text { Poulsen et al. } \\
\text { (2012) Australia }\end{array}$ & $\begin{array}{l}544 \text { cancer workers, } \\
\text { including nurses }(37 \%) ; \\
\text { radiation therapists }(22 \%) ; \\
\text { allied health and admin } \\
(23 \%) \text { and medical staff } \\
(8.5 \%) \text {. Majority female. }\end{array}$ & & $\begin{array}{l}+ \text { association with subjective } \\
\text { wellbeing }\end{array}$ & \\
\hline $\begin{array}{l}\text { Ratnasingam et al. } \\
\text { (2012) USA }\end{array}$ & $\begin{array}{l}143 \text { University employees } \\
\text { who were users of on-site } \\
\text { childcare programme }(n \\
=41) \text { or external childcare } \\
\text { programmes }(n=\quad 102) \\
\text { (mainly female and } \\
\text { married) }\end{array}$ & $\begin{array}{l}\text { association with family supportive } \\
\text { organization perceptions and childcare } \\
\text { satisfaction. Employees using on-site } \\
\text { childcare were less engaged when they } \\
\text { perceived their employer to be } \\
\text { unsupportive towards their family life and } \\
\text { were dissatisfied with their childcare } \\
\text { provider }\end{array}$ & + association with job satisfaction & \\
\hline $\begin{array}{ll}\text { Reissner } & \text { and } \\
\text { Pagan (2013) UK }\end{array}$ & $\begin{array}{l}\begin{array}{l}\text { Case study } \\
\text { private }\end{array} \text { public- } \\
\text { printnership } \\
\text { organization: Individual } \\
\text { interviews } \mathrm{N}=25 ; \text { group } \\
\text { interviews } \mathrm{N}=18 \text { in } 3 \\
\text { groups (senior \& middle }\end{array}$ & $\begin{array}{l}\text { Within the context of service delivery } \\
\text { though 'partnership' arrangements, } \\
\text { nature and quality of 'organizational } \\
\text { communication activities' as generative } \\
\text { of engagement, emphasising value of } \\
\text { directive and discursive exchanges } \\
\text { between managers and frontline staff }\end{array}$ & & \\
\hline
\end{tabular}




\begin{tabular}{|c|c|c|c|c|}
\hline Author/date/ & Study population & Antecedents & Morale Outcomes & Performance Outcomes \\
\hline & $\begin{array}{l}\text { manages / middle managers } \\
\text { / frontline employees) }\end{array}$ & $\begin{array}{l}\text { which changes 'lived experience' of } \\
\text { working for the company, e.g. reciprocity. } \\
\text { In contrast to earlier service delivery } \\
\text { model, employees report feelings of } \\
\text { greater control and being better informed } \\
\text { with greater commitment to } \\
\text { organizational goals. }\end{array}$ & & \\
\hline $\begin{array}{l}\text { Rich et al. (2010) } \\
\text { USA }\end{array}$ & $\begin{array}{l}245 \text { fire fighters (mainly } \\
\text { male) }\end{array}$ & $\begin{array}{l}+ \text { association with value congruence, } \\
\text { perceived organizational support, and } \\
\text { core self-evaluations. }\end{array}$ & & $\begin{array}{l}+ \text { association with task } \\
\text { performance and organizational } \\
\text { citizenship ratars. behaviors. } \\
\text { Engagement mediated the } \\
\text { relationships between value } \\
\text { congruence, ruporceived } \\
\text { organizational support, core-self } \\
\text { evaluations and task } \\
\text { performance/ organizational } \\
\text { citizenship behaviors. }\end{array}$ \\
\hline $\begin{array}{l}\text { Rickard et al. } \\
\text { (2012) Australia }\end{array}$ & 484 nurses and midwives & $\begin{array}{l}\text { A nurses' workload intervention at } \\
\text { organizational level including a nursing } \\
\text { workload tool, assessment of nursing } \\
\text { workloads, staff increases, personal } \\
\text { development, and a recruitment } \\
\text { campaign. Although there was a } \\
\text { significant reduction in psychological } \\
\text { distress, and a significant increase in job } \\
\text { satisfaction, there was no significant } \\
\text { increase in engagement. }\end{array}$ & & \\
\hline $\begin{array}{l}\text { Selmer et al. } \\
\text { (2013) Denmark }\end{array}$ & $\begin{array}{l}489 \text { academic staff within } \\
\text { natural } \\
\begin{array}{ll}\text { departments. } & \text { science }\end{array}\end{array}$ & $\begin{array}{l}\text { - association with group relational } \\
\text { conflict and }+ \text { association with group } \\
\text { trust. Size of department and group task } \\
\text { conflict only influenced cognitive } \\
\text { dimension of engagement. }\end{array}$ & & \\
\hline
\end{tabular}




\begin{tabular}{|c|c|c|c|c|}
\hline $\begin{array}{l}\text { Author/date/ } \\
\text { Location }\end{array}$ & Study population & Antecedents & Morale Outcomes & Performance Outcomes \\
\hline $\begin{array}{l}\text { Simbula } \quad(2010) \\
\text { Italy }\end{array}$ & $\begin{array}{l}61 \text { teachers. Majority } \\
\text { female. }\end{array}$ & $\begin{array}{l}\text { + association, at day level, with day-level } \\
\text { co-worker support }\end{array}$ & $\begin{array}{l}\text { - association, at general level, with } \\
\text { general emotional exhaustion and } \\
\text { general poor mental health, and + } \\
\text { association with general job } \\
\text { satisfaction. + association, at day- } \\
\text { level, with day-level job satisfaction } \\
\text { and- association with day level poor } \\
\text { mental health }\end{array}$ & \\
\hline $\begin{array}{l}\text { Spence } \\
\text { Laschinger (2010) } \\
\text { Canada }\end{array}$ & 322 acute care nurses. & $\begin{array}{l}+ \text { association with structural } \\
\text { empowerment (access to information, } \\
\text { support, resources, formal/informal } \\
\text { power) and four areas of worklife } \\
\text { (control, rewards, fairness, values) . } \\
\text { Neither workload nor community } \\
\text { influenced engagement. Areas of worklife } \\
\text { mediated the influence of structural } \\
\text { empowerment on engagement. }\end{array}$ & & \\
\hline $\begin{array}{l}\text { Spence } \\
\text { Laschinger (2012) } \\
\text { Canada }\end{array}$ & $\begin{array}{l}342 \text { nurses. } 40 \% \text { did not } \\
\text { choose nursing as 1st career } \\
\text { choice }\end{array}$ & & $\begin{array}{l}+ \text { association with job and career } \\
\text { satisfaction. - association with job } \\
\text { and career turnover intentions. }\end{array}$ & \\
\hline $\begin{array}{l}\text { Spence } \\
\text { Laschinger et al. } \\
\text { (2009) Canada }\end{array}$ & $\begin{array}{l}185 \text { new graduate nurses } \\
\text { and } 294 \text { acute care nurses }\end{array}$ & $\begin{array}{l}+ \text { association with structural } \\
\text { empowerment (access to information, } \\
\text { support, resources, formal/informal } \\
\text { power) }\end{array}$ & & $\begin{array}{l}+ \text { association with perceived } \\
\text { work effectiveness }\end{array}$ \\
\hline $\begin{array}{l}\text { Spence } \\
\text { Laschinger et al. } \\
\text { (2012) Canada }\end{array}$ & $\begin{array}{l}420 \text { newly graduated, } \\
\text { acute care nurses (mainly } \\
\text { female population) }\end{array}$ & $\begin{array}{l}+ \text { association with job resources } \\
\text { (consisting of supportive practice } \\
\text { environment and control) and with } \\
\text { psychological capital. }\end{array}$ & $\begin{array}{lll}\text { association } & \text { with } & \text { turnover } \\
\text { intentions } & & \end{array}$ & \\
\hline
\end{tabular}




\begin{tabular}{|c|c|c|c|c|}
\hline $\begin{array}{l}\text { Author/date/ } \\
\text { Location }\end{array}$ & Study population & Antecedents & Morale Outcomes & Performance Outcomes \\
\hline $\begin{array}{l}\text { Sulea et al. (2012) } \\
\text { Romania }\end{array}$ & $\begin{array}{lr}258 \text { employees } & \text { from three } \\
\text { organizations: } & \text { water } \\
\text { services and } & \text { sanitation; } \\
\text { town hall; } & \text { food } \\
\text { manufacturing. } & (86 \% \\
\text { public sector) } & \end{array}$ & $\begin{array}{l}+\quad \text { association with perceived } \\
\text { organizational support. - association with } \\
\text { interpersonal conflicts. }\end{array}$ & & $\begin{array}{l}\text { +association with organizational } \\
\text { citizenship behavior. } \\
\text { association with } \\
\text { counterproductive work } \\
\text { behavior. Engagement mediated } \\
\text { the relationship between } \\
\text { perceived organizational support } \\
\text { and organizational citizenship } \\
\text { behavior; and between. } \\
\text { interpersonal conflict at work } \\
\text { and counterproductive work } \\
\text { behavior. }\end{array}$ \\
\hline $\begin{array}{l}\text { Taipale et al. } \\
(2011) \text { Finland, } \\
\text { Sweden, UK, } \\
\text { Netherlands, } \\
\text { Germany, } \\
\text { Portugal, Hungary } \\
\text { and Bulgaria }\end{array}$ & $\begin{array}{l}7,869 \text { service sector } \\
\text { workers } 20 \% \text { of sample } \\
\text { worked in hospitals. }\end{array}$ & $\begin{array}{l}+ \text { association with social support and } \\
\text { autonomy. - association with work } \\
\text { demand pressure, but the impact was less } \\
\text { than that of autonomy or social support. } \\
\text { Weak interaction of demands and } \\
\text { resources. }\end{array}$ & & \\
\hline $\begin{array}{l}\text { Tanner et al. } \\
(2010) \\
\text { Switzerland }\end{array}$ & $\begin{array}{l}592 \text { employees from two } \\
\text { federal police departments. } \\
85 \% \text { male. }\end{array}$ & $\begin{array}{l}+ \text { association with ethical leadership } \\
\text { behavior }\end{array}$ & & \\
\hline $\begin{array}{l}\text { Van Beek et al. } \\
\text { (2012) China }\end{array}$ & $\begin{array}{l}544 \text { nurses }(99 \% \text { female }) \\
\text { and } 216 \text { physicians }(61 \% \\
\text { female). }\end{array}$ & $\begin{array}{l}\text { + association with identified regulation, } \\
\text { intrinsic motivation and introjected } \\
\text { regulation. }+ \text { association with job } \\
\text { resources (consisting of job control, social } \\
\text { support colleagues, social support } \\
\text { supervisor) Job demands (consisting of } \\
\text { work overload, mental demands, } \\
\text { emotional demands) were linked to } \\
\text { burnout rather than to engagement. }\end{array}$ & & \\
\hline $\begin{array}{l}\text { Van Bogaert et al. } \\
\text { (2013) Belgium }\end{array}$ & $\begin{array}{l}357 \text { staff from } 32 \text { clinical } \\
\text { units in two psychiatric } \\
\text { hospitals }\end{array}$ & $\begin{array}{l}\text { + associations with all three nurse practice } \\
\text { environment dimensions (nurse- } \\
\text { physician relations, unit-level nurse } \\
\text { management and hospital management - } \\
\text { organizational support). }\end{array}$ & $\begin{array}{l}+ \text { association with job satisfaction } \\
\text { and with intention to stay in the } \\
\text { profession }\end{array}$ & $\begin{array}{l}+ \text { association with quality of care } \\
\text { by the interdisciplinary team }\end{array}$ \\
\hline
\end{tabular}




\begin{tabular}{|c|c|c|c|c|}
\hline $\begin{array}{l}\text { Author/date/ } \\
\text { Location }\end{array}$ & Study population & Antecedents & Morale Outcomes & Performance Outcomes \\
\hline $\begin{array}{l}\text { Van den Broeck et } \\
\text { al. } \quad(2011) \\
\text { Netherlands }\end{array}$ & $\begin{array}{l}4,009 \text { public sector } \\
\text { employees (including } 14 \% \\
\text { healthcare). }\end{array}$ & $\begin{array}{l}+ \text { association with job resources } \\
\text { (autonomy, learning opportunities) and } \\
\text { intrinsic and extrinsic work values. - } \\
\text { association with emotional demands. No } \\
\text { direct association with workload and } \\
\text { engagement. However, workload } \\
\text { strengthened relationship between job } \\
\text { autonomy and engagement yet weakened } \\
\text { the relationship between learning } \\
\text { opportunities and engagement. These } \\
\text { effects were more pronounced for } \\
\text { employees with high intrinsic work } \\
\text { values. }\end{array}$ & & \\
\hline $\begin{array}{l}\text { Vera et al. (2010) } \\
\text { Spain }\end{array}$ & $\begin{array}{l}170 \text { University faculty } \\
\text { members; } 60 \% \text { male. }\end{array}$ & $\begin{array}{l}\text { Highest engagement amongst those } \\
\text { focusing on research work patterns. } \\
\text { Management work patterns showed } \\
\text { lowest engagement, with teaching work } \\
\text { patterns in between. }\end{array}$ & $\begin{array}{l}\text { Two dimensions (vigor and } \\
\text { dedication) - associated with all } 4 \\
\text { dimensions of burnout (exhaustion, } \\
\text { cynicism, depersonalisation, lack of } \\
\text { professional self-efficacy). All } 3 \\
\text { dimensions (vigor, dedication, } \\
\text { absorption) + associated with job } \\
\text { satisfaction }\end{array}$ & \\
\hline $\begin{array}{l}\text { Vogelgesang et al. } \\
\text { (2013) USA }\end{array}$ & $\begin{array}{l}453 \text { military cadets. } 78 \% \\
\text { male. }\end{array}$ & $\begin{array}{l}+ \text { lagged effects of group-level leader } \\
\text { communication transparency and leader } \\
\text { integrity. The effects of group-level } \\
\text { leader communication transparency on } \\
\text { individual follower engagement were } \\
\text { mediated by leader integrity. }\end{array}$ & & $\begin{array}{l}\text { +association with performance } \\
\text { evaluations }\end{array}$ \\
\hline $\begin{array}{l}\text { Weigl et al. (2010) } \\
\text { Germany }\end{array}$ & $\begin{array}{l}416 \text { hospital physicians } \\
\text { (mainly male) }\end{array}$ & $\begin{array}{l}\text { + lagged effects of job control, work } \\
\text { relationships, and active coping. }\end{array}$ & & \\
\hline
\end{tabular}




\begin{tabular}{|l|l|l|l|l|}
\hline $\begin{array}{l}\text { Author/date/ } \\
\text { Location }\end{array}$ & Study population & Antecedents & Morale Outcomes & Performance Outcomes \\
\hline $\begin{array}{l}\text { Wong et al. (2010) } \\
\text { Canada }\end{array}$ & $\begin{array}{l}280 \text { acute care nurses } \\
\text { working. 93.5\% female }\end{array}$ & $\begin{array}{l}\text { + association with authentic leadership, } \\
\text { personal identification with the manager, } \\
\text { social identification with the work unit, } \\
\text { and trust in the manager. }\end{array}$ & $\begin{array}{l}\text { association with voice } \\
\text { behavior and unit care quality. } \\
\text { Engagement was an important } \\
\text { mediating process } \\
\text { that } \\
\text { connected authentic leadership } \\
\text { with care quality. }\end{array}$ \\
\hline
\end{tabular}

